\title{
INFLUENCE OF DEVELOPMENT AND COLLAPSE OF THE OLD POLISH DISTRICT ON ENVIRONMENTAL CHANGES AND LAND USE DURING THE LAST 200 YEARS: CASE STUDY FROM CZARNA KONECKA RIVER BASIN (HOLY CROSS MTS. REGION, POLAND
}

\author{
DOI: https://doi.org/10.18509/AGB.2021.04 \\ UDC: 669:626.1/.4]:556.5(438)
}

\author{
Ewa Nowak ${ }^{1}$, Katarzyna Czaja², Tomasz Kalicki ${ }^{1}$
}

${ }^{1}$ Institute of Geography, and Environmental Sciences Jan Kochanowski University in Kielce, Poland ${ }^{2}$ Institute of Geography, Gdańsk University in Gdańsk, Poland

corresponding author: tomaszkalicki@ymail.com

\begin{abstract}
The aim of the study was recognizing the hydrotechnical infrastructure and metallurgical activity and changes in the structure of land use and its hydrographic network of the Czarna Konecka total catchment, and in Integrated Water Surface Parts (SCWP): SW0709, SW0710, SW0711 over the last 200 years. The analysis was based on a comparative analysis of cartographic material from various research periods. The development of the metallurgical industry in the period from the beginning of the 19th c. to the first half of the 20th c. caused a decrease in the forest's share in land cover and an increase in the length of watercourses. In the next 100 years, the area designated for renewal increased, but the species structure of the trees changed almost completely. Conifers were mainly used for afforestation. The increase in the length of watercourses was caused by the construction of drainage ditches, millers for the needs of water mills, mills, sawmills and for agriculture. In addition, many sections of the rivers were regulated and straightened. At the same time, due to the termination of many industrial plants, the area of water reservoirs drastically decreased until the first half of the 20th c. Many of them have been drained, or have been partially or completely silted up by sediments flowing in by rivers. The increase in standing water surface in the last about 100 years was caused by the construction of new water reservoirs, mainly for breeding ponds.
\end{abstract}

Keywords: Czarna Konecka catchment, changes in catchment use, hydrographic changes, Polish Uplands, Merged Surface Water Parts.

\section{STUDY AREA}

Czarna Konecka is the right tributary of the Pilica, which belongs to the Vistula River basin. It is about $85 \mathrm{~km}$ long. Its main tributaries are Barbarka, Krasna, Czarna Taraska and Plebanka. The Czarna Konecka total catchment to the estuary of Pilica covers an area of $972.6 \mathrm{~km} 2$ [2]. According to the division into physical-geographical regions [10], the research area is located in the province of the Polish Uplands, in the sub-province of the Lesser

\section{AIM OF THE STUDY AND METHODS}

The aim of the study was to trace changes in the structure of use and hydrographic network in the Czarna Konecka total catchment and separated Surface Water Parts (SCWP): SW0709, SW0710, SW0711 over the last about 200 years (Fig. 1). The combined surface water bodies consist of Surface Water Homogeneous Parts (JCWP). JCWP units
Poland Upland. Within the drainage catchment three Integrated Surface Water Parts (SCWP) were distinguished: SW0709, SW0710, SW0711 [15].

Until the end of the 19th century, the Czarna Konecka catchment was the most important industrial area in Poland in the field of iron mining and processing. In 1883, local metallurgical factories produced $50 \%$ of the iron produced at that time in the Polish Kingdom [5], [13].

are similar in terms of quantity, physicochemical, biological state and forms of land use, water and sewage management and hydrotechnical facilities [3], [4]. The research was based on a comparative analysis of cartographic material from various research periods (Table 1). 


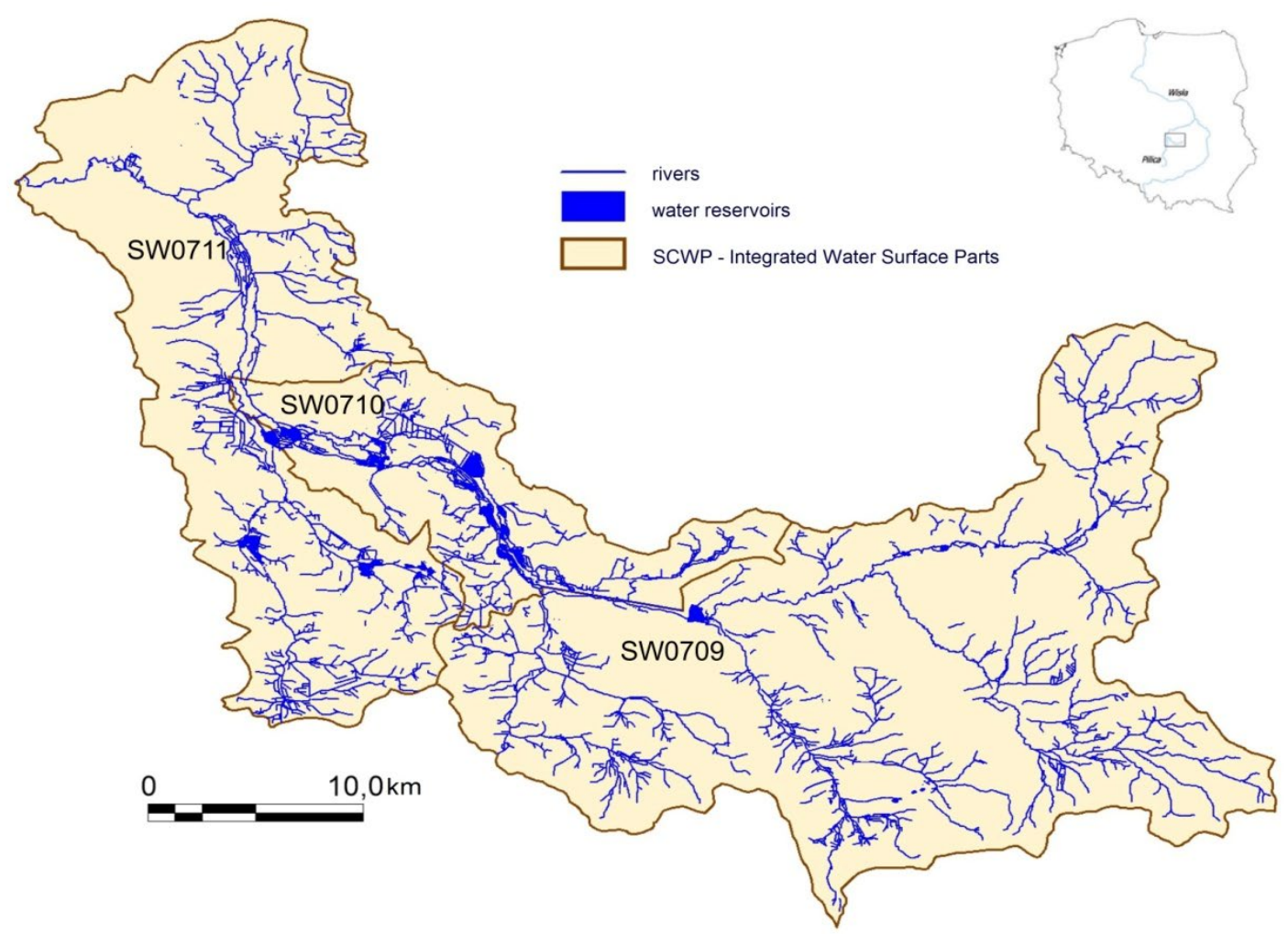

Figure 1. Integrated Surface Water Parts (SCWP) in the Czarna Konecka catchment area.

Table 1. Cartographic materials used in the study

\begin{tabular}{|l|l|c|c|}
\hline \multicolumn{1}{|c|}{ Time cutting } & \multicolumn{1}{|c|}{ Map } & Date of issue & Scale \\
\hline I - beginning of the $19^{\text {th }} \mathrm{c}$ & Karte von West-Gallizien & $1808 \mathrm{r}$. & $1: 172800$ \\
\hline II - first half of the $20^{\text {th }} \mathrm{c}$ & $\begin{array}{l}\text { Tactical map issued by the Military Geographic } \\
\text { Institute (WIG) }\end{array}$ & $\begin{array}{c}1922-1934 \\
\text { years }\end{array}$ & $1: 100000$ \\
\hline II - first half of the 20th c & Hydrographic map of Poland on a scale 1:50000 & $2004 \mathrm{r}$. & $1: 50000$ \\
\cline { 2 - 4 } & Corine Land Cover 2006 database (CLC2006) & $2006 \mathrm{r}$. & $1: 100000$ \\
\hline
\end{tabular}

On the Austrian "Karte von West-Galizien" maps and Polish maps issued by the WIG, a georeferencing process was carried out. They were Polish topographic maps from 2000 [6]. They were assigned one coordinate system - PUWG 1992 to avoid distortions resulting from the state of the cartographic background and to make it possible to compare the quantitative features of the examined objects [11]. The work uses the geographical information system (GIS) tool - MapInfo 11. The area of individual types of land use (forests,

\section{RESULTS}

At the beginning of the 19th century, almost $70 \%$ of the Czarna Konecka catchment area was covered by deciduous forests (Table 2; Fig. 2). In the period from the beginning of the 19th to the beginning of the 20th century, the share of forests fell to around $47 \%$. Deciduous trees dominated in the species structure of forests (Fig. 3). Coniferous forests covered only $0.5 \%$ of the basin area. By the beginning of the 21 st century, the share of forests agricultural areas, meadows, wetlands, anthropogenic areas) was generated, as well as the surface of water reservoirs and the length of watercourses. On the materials of the first half of the 20th c. additionally coniferous, deciduous and mixed forests were marked. In turn, Austrian maps do not have a legend. Therefore, it was not possible to separate agricultural areas, meadows and wetlands. These areas were treated as one whole and were called "other areas".

had increased. Currently, forests cover more than half of the basin area. Afforestation occurred in previously cleared land (Fig. 4). Over the century, however, there was almost complete replacement of species composition. Deciduous forests are currently less than $2 \%$ in the structure of use, while coniferous species currently account for over $70 \%$ of all forests). . 
Table 2. Percentage share of types of forests in the structure of land use of the

Czarna Konecka catchment at the beginning of the 19th, 20th and 21st century.

\begin{tabular}{|l|c|c|c|}
\hline \multicolumn{1}{|c|}{ Type } & $\begin{array}{c}\text { I- beginning of } \\
\text { the } 19^{\text {th }} \mathrm{c} .\end{array}$ & $\begin{array}{c}\text { II }- \text { first half of } \\
\text { the } 20^{\text {th }} \mathrm{c}\end{array}$ & $\begin{array}{c}\text { III - beginning of } \\
\text { the } 21^{\text {th }} \mathrm{c} .\end{array}$ \\
\hline forest & 68,0 & 46,8 & 50,9 \\
- coniferous & 0,0 & 0,5 & 37,1 \\
- deciduous & 68,0 & 46,3 & 1,9 \\
- mixed & - & 0,0 & 8,5 \\
- in a state of change & - & - & 3,4 \\
\hline arable land & \multirow{3}{*}{27,9} & 34,9 & 31,6 \\
\hline meadows & & 8,5 & 9,4 \\
\cline { 1 - 3 } wetland area i & 3,1 & 5,8 & 0,6 \\
\cline { 1 - 1 } anthropogenic areas & 1,0 & 3,8 & 7,0 \\
\hline watercourses & & 0,2 & 0,6 \\
\hline
\end{tabular}

Source: own study

From the first half of the 20th century to the beginning of the 21 st century, the wetland area has declined ten times - from almost $6 \%$ to just $0.6 \%$. In turn, the area of meadows during this period did not show clear changes. The situation was different in the case of anthropogenic areas. In the period from the beginning of the 19th to the first half of the 20th century, their total area increased from 3.1 to $3.8 \%$. However, a century later their area almost doubled - to $7.0 \%$. Over the 200 years, the hydrographic network has been characterized by high variability. The length of the streams of the area in question increased almost threefold. At the beginning of the 19th century, watercourses totaled $437.8 \mathrm{~km}$. In the first half of the 20th century their length was $736.9 \mathrm{~km}$ and at the beginning of the $21 \mathrm{st}$ century - $1264.5 \mathrm{~km}$. However, the overall surface of water reservoirs (over 1 ha) over the past 200 years showed a downward trend and decreased by almost half. At the beginning of the 19th century it had about 990 ha and two centuries later 545.2 ha.

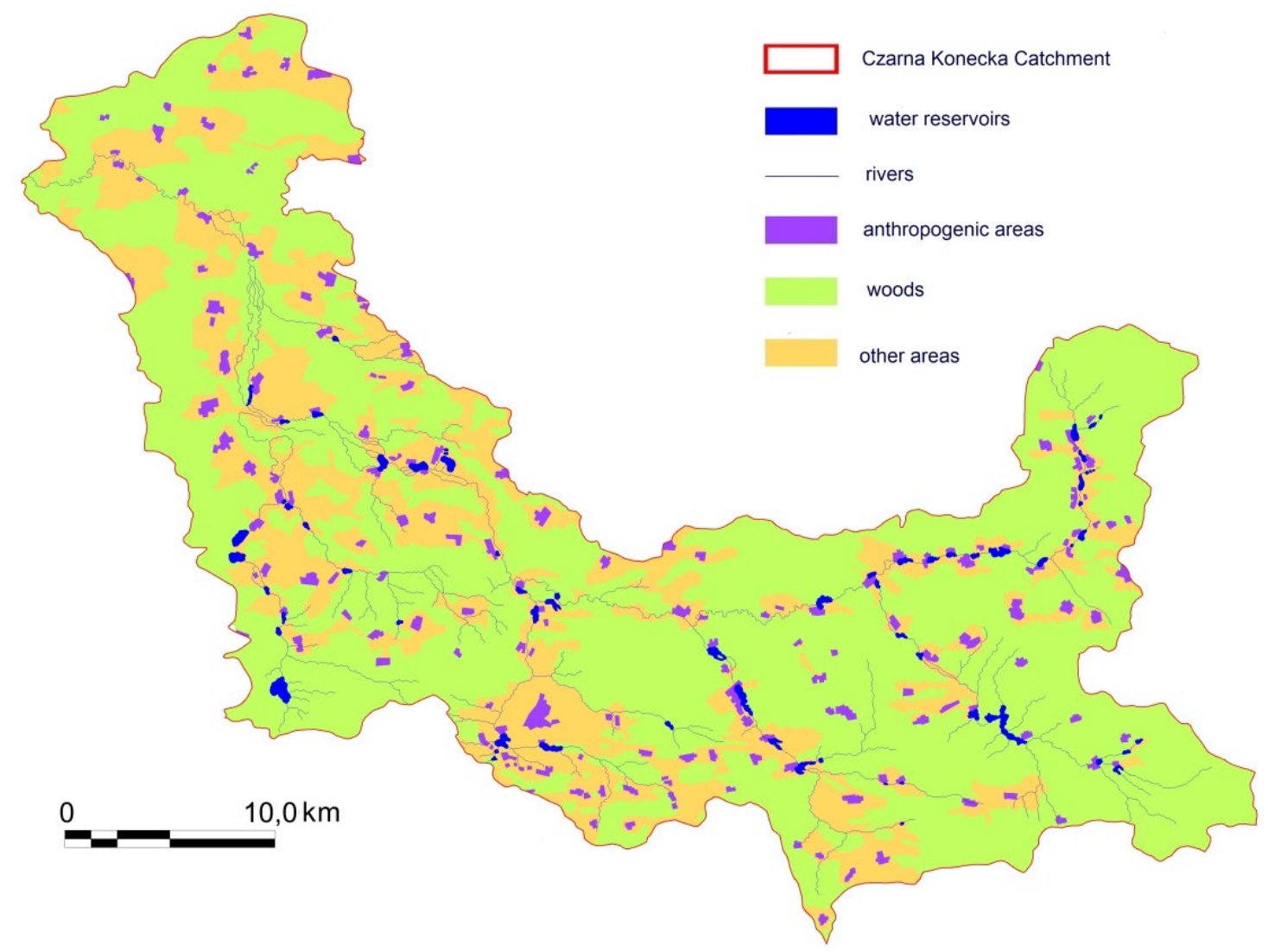

Figure 2. Land use and hydrographic network of the Czarna Konecka catchment at the beginning of the 19th century. 


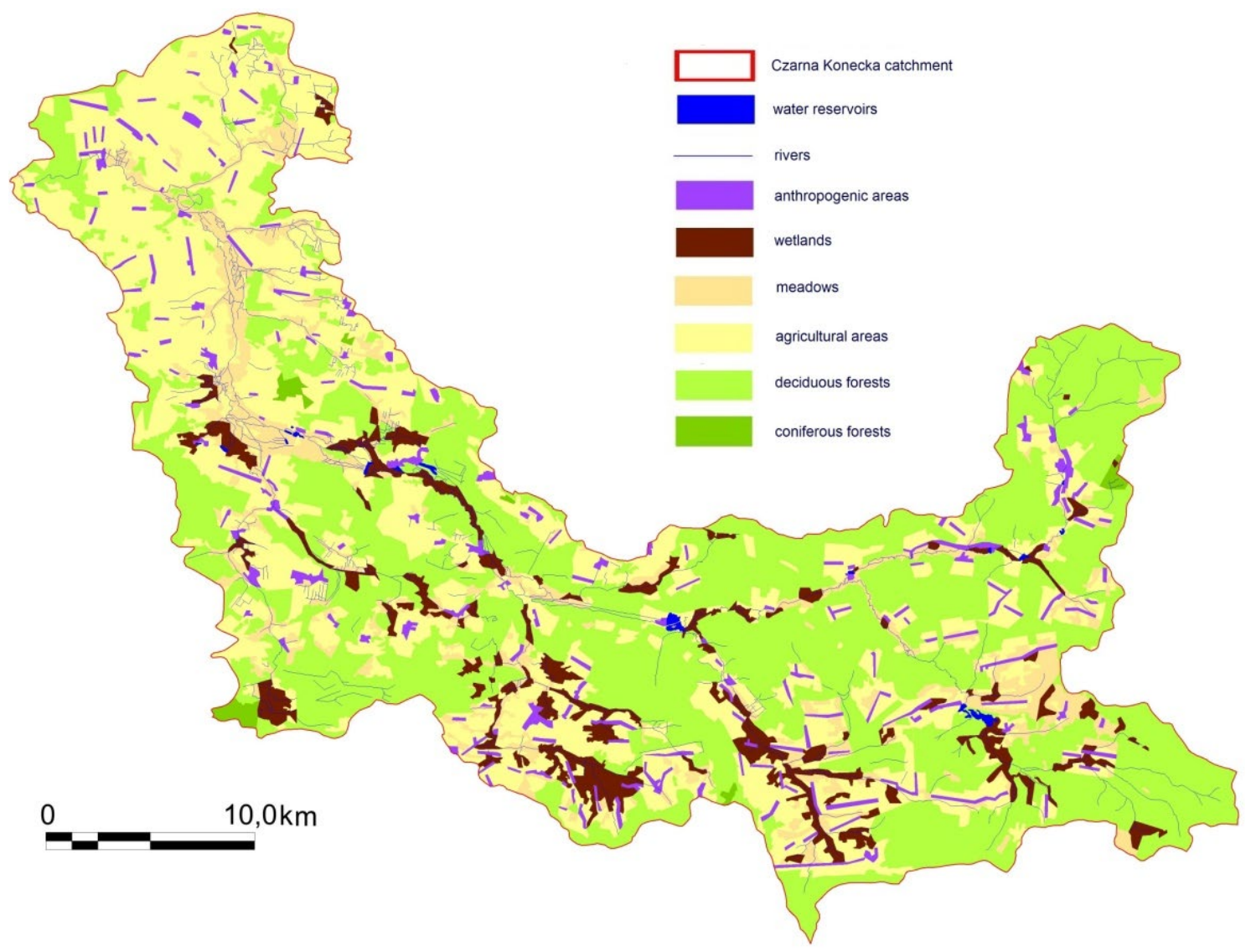

Figure 3. Land use and hydrographic network of the Czarna Konecka catchment in the first half of the 20th century.

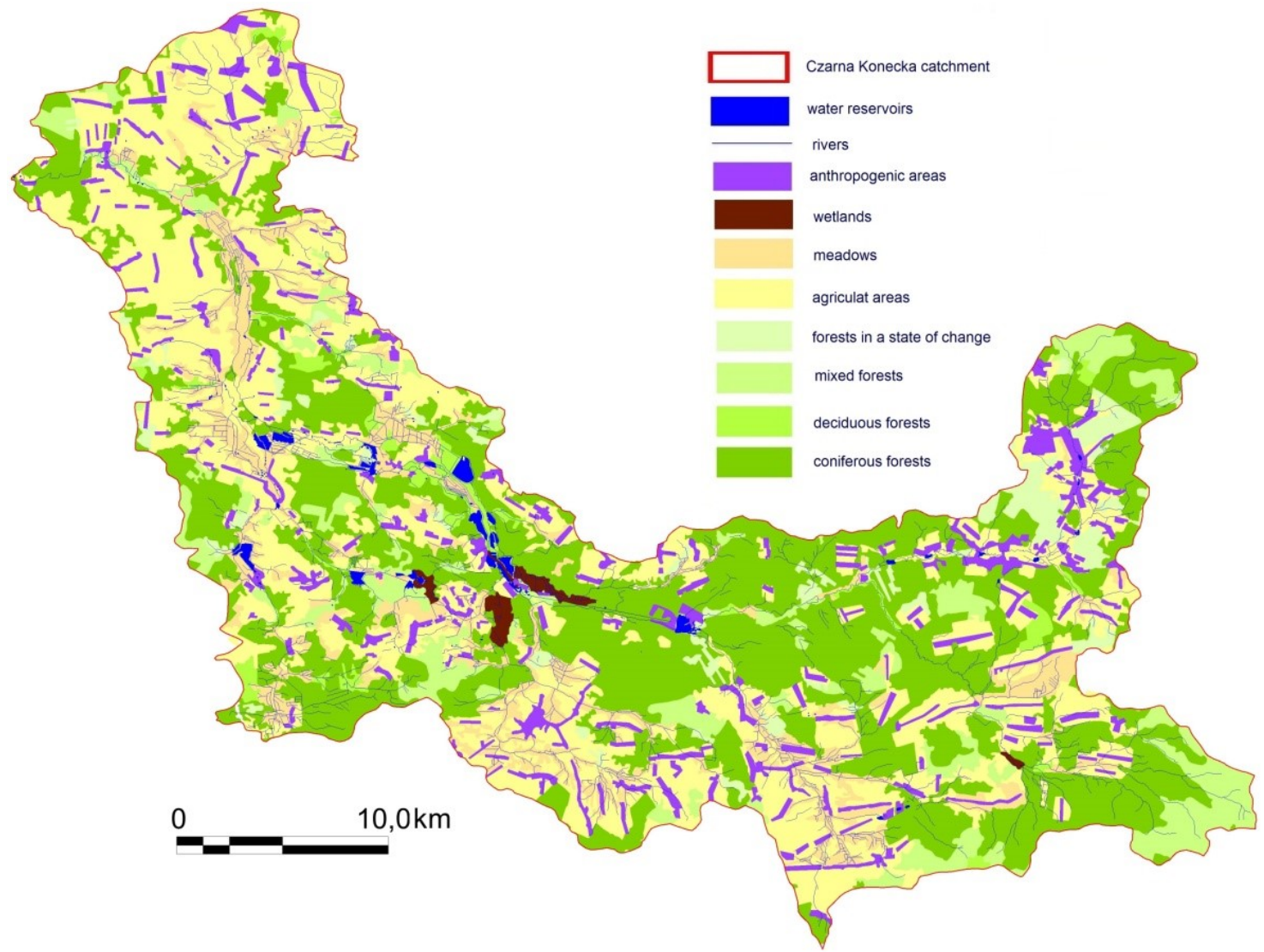

Figure 4. Land use and hydrographic network of the Czarna Konecka catchment at the beginning of the 21 st century. 
In the intermediate period, i.e. in the first half of the 20th century, water reservoirs were less than 180 ha. With the change in the surface of standing waters, their number changed. At the beginning of the 19th century, sixty-three reservoirs existed throughout the basin. Over the next century, this value decreased more than ten times and only six of them were reproduced in the image from the beginning of the 20th century. At the beginning of the 21 st century, the surface of water reservoirs
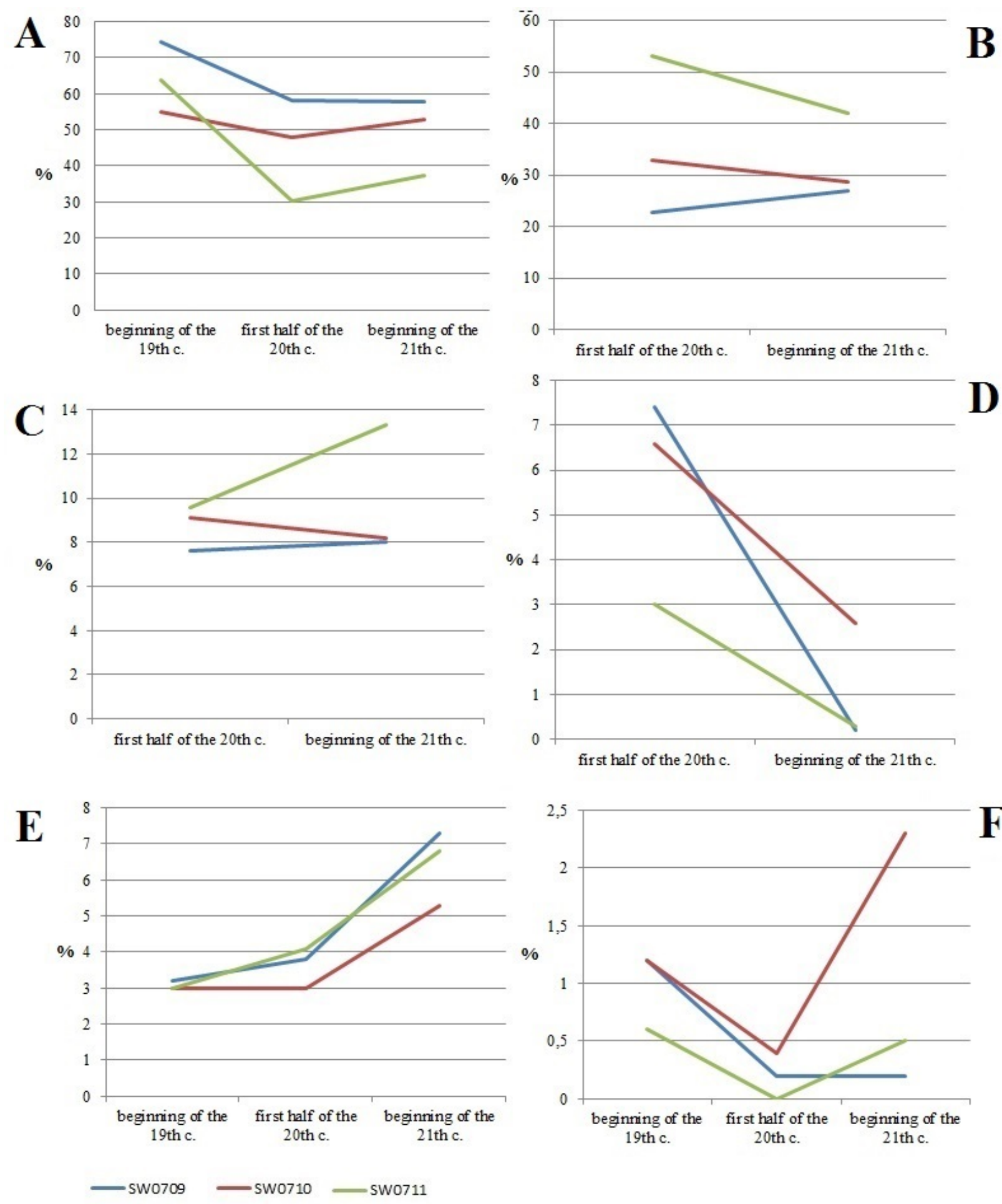
appeared, covering over 450 ha.The above described changes in land use and hydrographic network had different intensities in the Integrated Surface Water Parts: SW0709, SW0710 and SW0711. Unit SW0711 was the most agricultural area. About 100 years ago, arable land covered more than half of SW0711, and at the beginning of the 21 st century over $40 \%$ (Fig. 6 ).

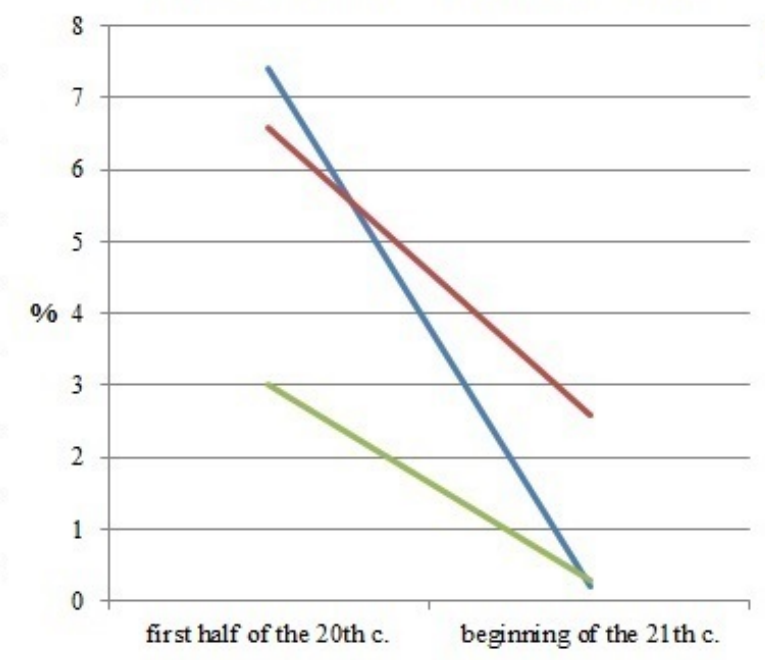

D

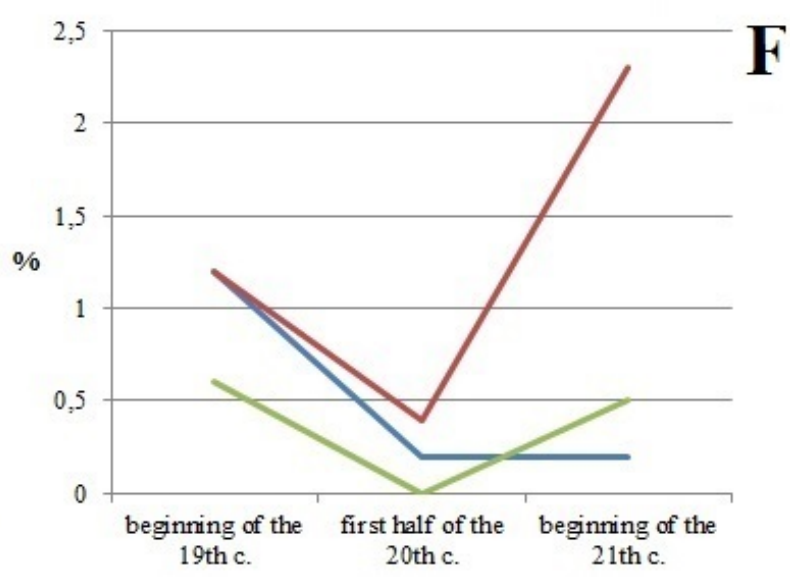

Figure 5. Changes in the percentage share of: forests (A), agricultural areas (B), meadows (C), wetlands (D), anthropogenic areas (E), surface waters (F) in the Integrated Parts of Surface Water: SW0709, SW0710, SW0711 in last 200 years. 


\section{Ewa Nowak, Katarzyna Czaja, Tomasz Kalicki

This unit also recorded the largest percentage decrease in the share of forests in land cover in the period from the first half of the 20th century to the beginning of the 21st century. Only in SW0711 an increase in the area of meadows was noted over the last century. This area was also distinguished by the fact that the increase in the length of watercourses and anthropogenic areas was continuous, and the changes in the share of standing waters, as in SW0710, variable (Fig. 5). In the period from the beginning of the 19th century to the first half of the 20th century, there was a drastic decrease in the surface of water reservoirs in SW0711 and SW0710. During the next 100 years in SW0711, due to the appearance of the pond on the Barbarka River, this area increased, reaching a level similar to that of two centuries ago. Whereas in SW0710, due to the construction of breeding ponds, among others: Praga, Czapla, Cieklińsko, the share of standing waters in relation to the value from the beginning of the 20th century increased almost five times. In SW0711, over the past 200 years, watercourses have more than tripled and the share of anthropogenic areas more than doubled. The course and level of changes in anthropogenic areas was similar to changes in SW0709. However, SW0709 was the only one to be distinguished by the abrupt drop in stagnant water surface. As a result of the fall of industry, the surface of water reservoirs decreased until the first half of the 20th century. The joints were silted up. They were also dried. During the next century, their surface showed no change. This was due to the damming of the Czarna Konecka River and the creation of the Sielpia Reservoir with an area of about 50 ha for the needs of the rolling mill in 1821 . However, due to the disappearance of ponds in the upper reaches of Czarna Konecka River, its surface and depth changed, which in 2008 did not exceed $50 \mathrm{~cm}$ [1], [7], [8], [9], [14]. The units SW0709 and SW0710 were similar in terms of the share of forests, arable land and meadows, although the changes had a different direction.

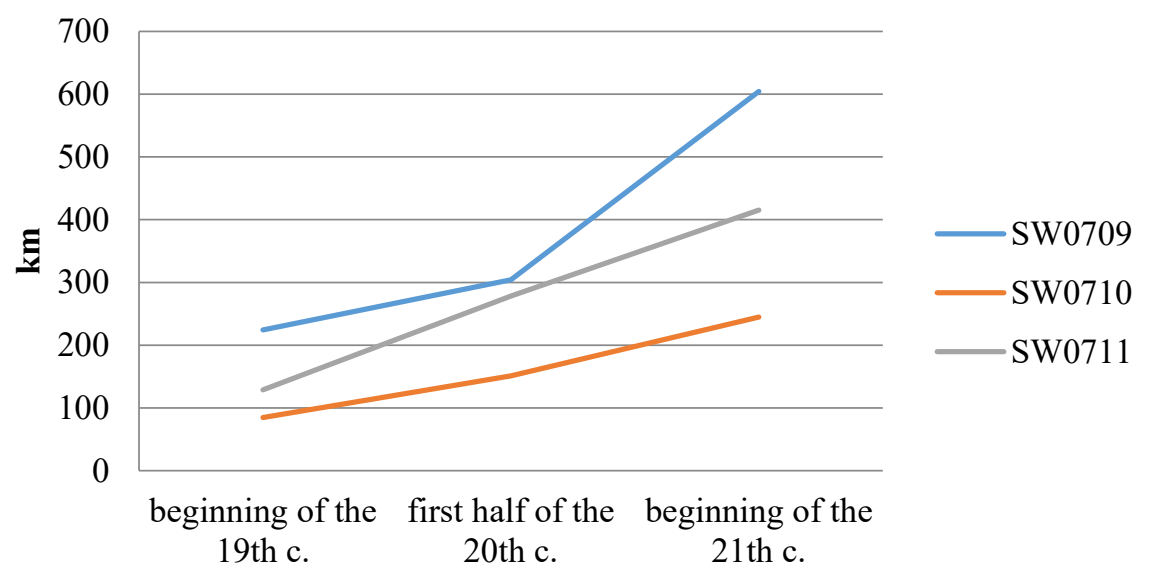

Figure 6. Watercourse lengths in Integrated Surface Water Parts: SW0709, SW0710 and SW0711 at the beginning of the 19th century, in the first half of the 20th century and at the beginning of the 21 th century.

\section{CONCLUSION}

The research results indicate that changes in the structure of land use and the hydrographic network in the Czarna Konecka River drainage basin, belonging to the most important industrial areas of the Old Polish Industrial District, were associated with the activities of industrial plants. In addition to the network of rivers and rich deposits of iron ore, the development of metallurgy in the Czarna Konecka River Valley was determined by the high forest cover of these areas [12].

The development of the metallurgical industry in the period from the beginning of the 19th century to the first half of the 20th century caused a decrease in the forest's share in land cover and an increase in the length of watercourses. In the next 100 years, the area designated for renewal increased, but the structure of the trees species changed almost completely. Conifers were mainly used for afforestation. The increase in the length of the watercourses was caused by the construction of drainage ditches and canals, millers for the needs of water mills, flour mills, sawmills and for agriculture. At the same time, due to the termination of many industrial plants, the area and number of water reservoirs drastically decreased to the first half of the 20th century.

In the 19th and 20th centuries, water forges, in the 20 th century mills and sawmills closed down. Many of them have been drained or have been partially or completely silted up by settlements flowing in by rivers. The increase in standing water surface in the last about 100 years was caused by the construction 
of new water reservoirs, mainly for breeding ponds. With the change in surface and number of tanks, their function changed. Due to the fact that the metallurgical industry did not develop evenly throughout the Czarna Konecka River basin area, the areas of Integrated Surface Water Parts:
SW0709, SW0710 and SW0711 were characterized by a different structure of land use and hydrographic network. The changes taking place in these units over the space of the last two centuries had a different course and pace. It was related to conducting other forms of activity.

\section{REFERENCES}

[1] Aksamit M., Kusztal P., Kalicki T., Grzeszczyk P., Przepióra P., Silting of the Sielpia Water reservoir in the 20th and 21st C. (Central Poland), International Scientific Conference Geobalcanica 2019, pp 101-105, 2019.

[2] Atlas Podziału Hydrograficznego Polski, 2005.

[3] Barszczyńska M., Kubacka D., Ramowa Dyrektywa Wodna: Znaczące oddziaływania antropogeniczne na wody rzek Polski, Chrońmy Przyrodę Ojczystą 64 (5), pp 28-42, 2008.

[4] Bukowiec T., Grela J., Owsiany M., Wybrane aspekty scalania jednolitych części wód powierzchniowych na potrzeby procesu planowania gospodarki wodnej w zlewni Sanu. „III Międzynarodowa Konferencja NaukowoTechniczna „Błękitny San” 21-22 kwietnia 2006 r., Dubiecko”, 2006.

[5] Chłopek M., Dolina Czarnej: zapomniane dziedzictwo, Stowarzyszenie „W Dolinie Czarnej”, Zabytkowy Zakład Hutniczy w Maleńcu (skład i łamanie Robert Świąder), Maleniec, 2017.

[6] Jankowska M., Wybrane problemy oceny wartości użytkowej mapy zmian stosunków wodnych w czasie, [in:] Kartograficzne metody badania zmian środowiska, Wyd. AR, Poznań, pp 81-84, 1997.

[7] Kalicki T., Fularczyk K., Zmiany biegu koryta Krasnej (Świętokrzystkie) w oparciu o dane kartograficzne i geologiczne, Acta Universitatis Lodziensis, Folia Geographica Physica 17, pp 15-23, 2018.

[8] Kalicki T., Przepióra P., Kusztal P., Orgin and effects of antropogenic flash floods on river of Holy Cross Mtr. Region (Poland) in 20th c., Acta Geobalcanica, 5-2, pp 85-92, 2019.

[9] Kalicki T., Przepióra P., Kusztal P., Antropogeniczne powodzie błyskawiczne na dwóch wybranych rzekach świętokrzyskich w XX w - przyczyni i skutki, Prace i Studia Geograficzne, t. 64.1, pp 21-36, 2019.

[10] Kondracki J., Geografia regionalna Polski, Wydawnictwo Naukowe PWN, Warszawa, 2001.

[11] Kubiak J., Ławniczak R., Dokładność położenia linii brzegowej wybranych jezior zachodniej części Pojezierza Międzychodzko-Sierakowskiego na mapach topograficznych w skali 1:10 000, 1:25 000 i 1:50 000, Polski Przegląd Kartograficzny, T. 44, z. 4, pp 342-348, 2012.

[12] Nowak E., Region konecki - kuźnią Europy, [in:] E. Nowak (ed.), Tradycje i współczesność działalności przemysłowej na terenie Staropolskiego Okręgu Przemysłowego, Nauki Geograficzne w Badaniach Regionalnych, Instytut Geografii Akademii Świętokrzyskiej im. Jana Kochanowskiego w Kielcach, Oddział Kielecki Polskiego Towarzystwa Geograficznego, tom VI, 2007.

[13] Połujański A., Opisanie lasów Królestwa Polskiego i guberni zachodniej Cesarstwa Rosyjskiego, T. I, Warszawa, pp 271, 1854.

[14] Szot-Radziszewska E., Postindustrialne dziedzictwo Staropolskiego Okręgu Przemysłowego w krajobrazie kulturowym Kielecczyzny: zagrożenia i szanse, Ochrona Zabytków, Vol. 62, no. 4, pp 69-82, 2009.

[15] Tyszewski S., Pusowska D., Warunki korzystania z wód zlewni Czarnej Malenieckiej, Warszawa, 2012. 